MSC 34A55, 65M32, 65L09

DOI: $10.14529 / \mathrm{mmp190202}$

\title{
INVERSE PROBLEM FOR SOBOLEV TYPE MATHEMATICAL MODELS
}

\author{
A.A. Zamyshliaeva ${ }^{1}$, A.V. Lut ${ }^{1}$ \\ ${ }^{1}$ South Ural State University, Chelyabinsk, Russian Federation \\ E-mails: zamyshliaevaaa@susu.ru, lutav@susu.ru
}

\begin{abstract}
The work is devoted to the study of an inverse problem for the linear Sobolev type equation of higher order with an unknown coefficient depending on time. Since the equation might be degenerate the phase space method is used. It consists in construction of projectors splitting initial spaces into a direct sum of subspaces. Actions of operators also split. Therefore, the initial problem is reduced to two problems: regular and singular. The regular one is reduced to the first order nondegenerate problem which is solved via approximations. The needed smoothness of the solution is obtained. Then it is substituted into the singular problem which is solved using the methods of relatively polynomially bounded operator pencils theory. The main result of the work contains sufficient conditions for the existence and uniqueness of the solution to the inverse problem for a complete Sobolev type model of the second order. This technique can be used to investigate inverse problems of the considered type for Boussinesq-Love mathematical model.

Keywords: Sobolev type equation; inverse problem; mathematical models; equation of second order.

Dedicated to the 60-th birthday of outstanding mathematician Jacek Banasiak.
\end{abstract}

\section{Introduction}

Let $\mathcal{U}, \mathcal{F}, \mathcal{Y}$ be Banach spaces, operators $A \in \mathcal{L}(\mathcal{U} ; \mathcal{F})$, ker $A \neq\{0\}, B_{1}, B_{0} \in$ $\mathcal{C l}(\mathcal{U} ; \mathcal{F}), C \in \mathcal{L}(\mathcal{U} ; \mathcal{Y})$, the functions $\chi:[0, T] \rightarrow \mathcal{L}(\mathcal{Y} ; \mathcal{F}), f:[0, T] \rightarrow \mathcal{F}, \Psi:[0, T] \rightarrow \mathcal{Y}$. Consider the following problem

$$
\begin{gathered}
A v^{\prime \prime}(t)=B_{1} v^{\prime}(t)+B_{0} v(t)+\chi(t) q(t)+f(t), \quad t \in[0, T], \\
v(0)=v_{0}, \\
v^{\prime}(0)=v_{1}, \\
C v(t)=\Psi(t) .
\end{gathered}
$$

One of the prototypes of equation (1) is

$$
(\lambda-\Delta) v_{t t}=\alpha\left(\Delta-\lambda^{\prime}\right) v_{t}+\beta\left(\Delta-\lambda^{\prime \prime}\right) v+g,
$$

which models, among others, the incompressible fluid free surface perturbation under the assumption of motion potentiality and conservation of mass in a layer [1], longitudinal vibrations of an elastic rod [2] and wave processes in smectic and plasma [3]. The problem 
of finding a pair of functions $v(t) \in C^{2}([0, T] ; \mathcal{U})$ and $q(t) \in C^{1}([0, T] ; \mathcal{Y})$ from relations (1) - (4) is called the inverse problem.

Equation (1) refers to Sobolev type equations, since the operator $A$ can be degenerate. Equations of this type of the first order are well studied. For example, there were proved the existence and uniqueness of classical solutions in the case of relatively sectorial operators [4], and [5] presented sufficient conditions for the unique solvability of the inverse problem using semigroups theory. In addition, there are articles devoted to the study of initialfinal problems [6,7], as well as to a numerical study of equations on the graphs [8], where the solution is sought in the form of the Galerkin sum. Sobolev type equations find their application in solving various technical problems, such as in [9]. Higher order equations were studied in [10] and [11] in the case of relatively bounded operator pencils. Semigroups theory finds application also in mathematical bioscience [12].

Problem (1) - (4) is inverse since, in addition to finding the function $v(t)$, we need to restore the function $q(t)$. Inverse problems were studied for the heat equation [13], for the second-order hyperbolic equations $[14,15]$, and also for the multidimensional wave equation of the second order [16].

\section{Preliminary Information and Reduction of Initial Inverse Problem}

To find a pair of functions $v(t)$ and $q(t)$ we use the results obtained in the research of higher order Sobolev type equations [17]. Denote by $\vec{B}$ the pencil of operators $B_{1}, B_{0}$.

Definition 1. The pencil $\vec{B}$ is called polynomially A-bounded if

$$
\exists a \in \mathbb{R}_{+} \quad \forall \mu \in \mathbb{C} \quad(|\mu|>a) \Rightarrow\left(R_{\mu}^{A}(\vec{B}) \in \mathcal{L}(\mathcal{F} ; \mathcal{U})\right) .
$$

Introduce an important condition:

$$
\int_{\gamma} R_{\mu}^{A}(\vec{B}) d \mu \equiv \mathbb{O}
$$

where $\gamma=\{\mu \in \mathbb{C}:|\mu|=r>a\}$.

Lemma 1. Let the pencil $\vec{B}$ be polynomially A-bounded and condition (A) be fulfilled. Then the operators

$$
P=\frac{1}{2 \pi i} \int_{\gamma} R_{\mu}^{A}(\vec{B}) \mu A d \mu \in \mathcal{L}(\mathcal{U}), \quad Q=\frac{1}{2 \pi i} \int_{\gamma} \mu A R_{\mu}^{A}(\vec{B}) d \mu \in \mathcal{L}(\mathcal{F})
$$

are projectors.

Put $\mathcal{U}^{0}=\operatorname{ker} P, \mathcal{F}^{0}=\operatorname{ker} Q, \mathcal{U}^{1}=i m P, \mathcal{F}^{1}=i m Q$. From the previous Lemma it follows that $\mathcal{U}=\mathcal{U}^{0} \oplus \mathcal{U}^{1}, \mathcal{F}=\mathcal{F}^{0} \oplus \mathcal{F}^{1}$. Let $A^{k}\left(B_{l}^{k}\right)$ denote the restriction of the operator $A\left(B_{l}\right)$ onto $\mathcal{U}^{k}, k=0,1 ; l=0,1$.

Theorem 1. Let the pencil $\vec{B}$ be polynomially A-bounded and condition (A) be fulfilled. Then the actions of the operators split: 
(i) $A^{k} \in \mathcal{L}\left(\mathcal{U}^{k} ; \mathcal{F}^{k}\right), k=0,1$

(ii) $B_{l}^{k} \in \mathcal{L}\left(\mathcal{U}^{k} ; \mathcal{F}^{k}\right), k=0,1, l=0,1$;

(iii) there exists an operator $\left(A^{1}\right)^{-1} \in \mathcal{L}\left(\mathcal{F}^{1} ; \mathcal{U}^{1}\right)$;

(iv) there exists an operator $\left(B_{0}^{0}\right)^{-1} \in \mathcal{L}\left(\mathcal{F}^{0} ; \mathcal{U}^{0}\right)$.

Definition 2. Define the family of operators $\left\{K_{q}^{1}, K_{q}^{2}\right\}$ as follows:

$K_{1}^{1}=H_{0}, K_{1}^{2}=-H_{1}$,

$K_{q+1}^{1}=K_{q}^{2} H_{0}, K_{q+1}^{2}=K_{q}^{1}-K_{q}^{2} H_{1}, q=1,2, \ldots$

where $H_{0}=\left(B_{0}^{0}\right)^{-1} A^{0} ; H_{1}=\left(B_{0}^{0}\right)^{-1} B_{1}^{0}$.

Definition 3. The point $\infty$ is called

( $i$ ) a removable singular point of the $A$-resolvent of pencil $\vec{B}$, if $K_{1}^{1} \equiv \mathbb{O}, K_{1}^{2} \equiv \mathbb{O}$;

(ii) a pole of order $p \in \mathbb{N}$ of the A-resolvent of pencil $\vec{B}$, if $K_{p}^{1} \not \equiv \mathbb{O}$ or $K_{p}^{2} \not \equiv \mathbb{O}$, but $K_{p+1}^{1} \equiv \mathbb{O}, K_{p+1}^{2} \equiv \mathbb{O}$

(iii) an essentially singular point of the A-resolvent of the pencil $\vec{B}$, if $K_{k}^{2} \not \equiv \mathbb{O}$ for any $k \in \mathbb{N}$.

Let the pencil $\vec{B}$ be polynomially $A$-bounded and condition (A) be fulfilled, then $v(t)$ can be represented as $v(t)=P v(t)+(I-P) v(t)=u(t)+\omega(t)$. Suppose that $\mathcal{U}^{0} \subset \operatorname{ker} C$. Then, by virtue of Theorem 1 and Lemma 1, problem $(1)-(4)$ is equivalent to the problem of finding the functions $u \in C^{2}\left([0, T] ; \mathcal{U}^{1}\right), \omega \in C^{2}\left([0, T] ; \mathcal{U}^{0}\right), q \in C^{1}([0, T] ; \mathcal{Y})$ from the relations

$$
\begin{gathered}
u^{\prime \prime}(t)=S_{1} u^{\prime}(t)+S_{0} u(t)+\left(A^{1}\right)^{-1} Q \chi(t) q(t)+\left(A^{1}\right)^{-1} Q f(t), \\
u(0)=u_{0}, u^{\prime}(0)=u_{1}, \\
C u(t)=\Psi(t) \equiv C v(t), \\
H_{0} \omega^{\prime \prime}(t)=H_{1} \omega^{\prime}(t)+\omega(t)+\left(B_{0}^{0}\right)^{-1}(I-Q) \chi(t) q(t)+\left(B_{0}^{0}\right)^{-1}(I-Q) f(t), \\
\omega(0)=\omega_{0}, \omega^{\prime}(0)=\omega_{1},
\end{gathered}
$$

where $S_{1}=\left(A^{1}\right)^{-1} B_{1}^{1}, \quad S_{0}=\left(A^{1}\right)^{-1} B_{0}^{1}, \quad u_{0}=P v_{0}, \quad u_{1}=P v_{1}, \omega_{0}=(I-P) v_{0}$, $\omega_{1}=(I-P) v_{1}, t \in[0, T]$. The inverse problem $(5)-(7)$ is called regular, and problem (8), (9) is called singular.

\section{Solution of the Regular Inverse Problem}

Rewrite problem $(5)-(7)$ in the notation [18]. Let $\mathcal{X}, \mathcal{Y}$ be Banach spaces, operators $S_{1}, S_{0} \in \mathcal{C l}(\mathcal{X}), C \in \mathcal{L}(\mathcal{X}, \mathcal{Y})$, operator-function $\Phi:[0, T] \rightarrow \mathcal{L}(\mathcal{Y} ; \mathcal{X})$, functions $h:[0, T] \rightarrow \mathcal{X}, \Psi:[0, T] \rightarrow \mathcal{Y}$

$$
\begin{gathered}
u^{\prime \prime}(t)=S_{1} u^{\prime}(t)+S_{0} u(t)+\Phi(t) q(t)+h(t), t \in[0, T], \\
u(0)=u_{0}, u^{\prime}(0)=u_{1}, \\
C u(t)=\Psi(t) .
\end{gathered}
$$

Theorem 2. Let the pencil $\vec{B}$ be polynomially A-bounded and condition (A) be fulfilled, moreover, $C \in \mathcal{L}(\mathcal{X} ; \mathcal{Y}), \Phi \in C^{1}([0, T] ; \mathcal{L}(\mathcal{Y} ; \mathcal{X})), h \in C^{1}([0, T] ; \mathcal{X}), \Psi \in C^{3}([0, T] ; \mathcal{Y})$, for any $t \in[0, T]$ the operator $C \Phi(t)$ be invertible and $(C \Phi)^{-1} \in C^{1}([0, T] ; \mathcal{L}(\mathcal{Y}))$. 
If the compatibility condition $C u_{1}=\Psi^{\prime}(0)$ is satisfied, then the solution to the inverse problem (10) - (12) exists and is unique in the class of functions $q \in C^{1}([0, T] ; \mathcal{Y}), u \in C^{2}([0, T] ; \mathcal{X})$.

Proof. Reduce problem (10) - (12) to the problem for the first order equation

$$
\begin{gathered}
v^{\prime}(t)=A v(t)+Q(t) q(t)+F(t), \quad t \in[0, T], \\
v(0)=v_{0}, \\
B v(t)=Z(t),
\end{gathered}
$$

where $v(t)=\left(\begin{array}{c}u(t) \\ u^{\prime}(t)\end{array}\right), A=\left(\begin{array}{cc}0 & I \\ S_{0} & S_{1}\end{array}\right), Q(t)=\left(\begin{array}{c}0 \\ \Phi(t)\end{array}\right), F(t)=\left(\begin{array}{c}0 \\ h(t)\end{array}\right)$, $v(0)=\left(\begin{array}{c}u(0) \\ u^{\prime}(0)\end{array}\right), v_{0}=\left(\begin{array}{l}u_{0} \\ u_{1}\end{array}\right), B=\left(\begin{array}{ll}0 & C\end{array}\right), Z(t)=\Psi^{\prime}(t)$.

Put $R(t)=-(C \Phi(t))^{-1}$. Therefore, all the conditions of Theorem 6.2.3 from [18], are satisfied, and the function $q(t)$ satisfies the integral equation

$$
q(t)=q_{0}(t)+R(t)\left(C S_{0} \int_{0}^{t} V_{12}(t-s) \Phi(s) q(s) d s+C S_{1} \int_{0}^{t} V_{22}(t-s) \Phi(s) q(s) d s\right)
$$

where

$$
\begin{gathered}
q_{0}(t)=-R(t)\left(\Psi^{\prime \prime}(t)-C S_{0} V_{11}(t) u_{0}-C S_{1} V_{21}(t) u_{0}-C S_{0} V_{12}(t) u_{1}-C S_{1} V_{22}(t) u_{1}-\right. \\
\left.-C S_{0} \int_{0}^{t} V_{12}(t-s) h(s) d s-C S_{1} \int_{0}^{t} V_{22}(t-s) h(s) d s-C h(t)\right) .
\end{gathered}
$$

Thus, the solution to the inverse problem (13) - (15) exists and is unique in the class of functions $q \in C^{1}([0, T] ; \mathcal{Y}), \quad v \in C^{1}\left([0, T] ; \mathcal{X}^{2}\right)$. Thus, we obtain that the solution to the regular inverse problem (10) - (12) exists and is unique, with $q \in C^{1}([0, T] ; \mathcal{Y}), u \in C^{2}([0, T] ; \mathcal{X})$.

In order to obtain a solution to a singular problem, we need a greater smoothness of the function $q$ from the solution of a regular problem.

Lemma 2. Let $n \in \mathbb{N}, V \in C^{n-1}([0, T] ; \mathcal{L}(\mathcal{X})), g \in C^{n}([0, T] ; \mathcal{X})$. Then

$$
\left(\int_{0}^{t} V(t-s) g(s) d s\right)^{(n)}=\sum_{k=0}^{n-1} V^{(n-k-1)}(t) g^{(k)}(0)+\int_{0}^{t} V(t-s) g^{(n)}(s) d s .
$$

Proof. Apply the method of mathematical induction. First we show that for $n=1$ formula (17) is true. Find the first derivative with respect to $t$

$$
\begin{gathered}
\left(\int_{0}^{t} V(t-s) g(s) d s\right)_{t}^{\prime}=V(0) g(t)+\int_{0}^{t} \frac{d}{d t}[V(t-s)] g(s) d s=V(0) g(t)- \\
-\int_{0}^{t} \frac{d}{d s}[V(t-s)] g(s) d s=V(t) g(0)+\int_{0}^{t} V(t-s) g^{\prime}(s) d s .
\end{gathered}
$$


Comparing (17) and (18) we conclude that formula (17) for $n=1$ is true. Now show that if (17) is true for $n$, then it is also true for $n+1$ :

$$
\begin{gathered}
\left(\left(\int_{0}^{t} V(t-s) g(s) d s\right)^{(n)}\right)_{t}^{\prime}=\sum_{k=0}^{n-1} V^{(n-k)}(t) g^{(k)}(0)+V(t) g^{(n)}(0)+\int_{0}^{t} V(t-s) g^{(n+1)}(s) d s= \\
=\sum_{k=0}^{n} V^{(n-k)}(t) g^{(k)}(0)+\int_{0}^{t} V(t-s) g^{(n+1)}(s) d s=\left(\int_{0}^{t} V(t-s) g(s) d s\right)^{(n+1)} .
\end{gathered}
$$

The following theorem provides sufficient conditions for the existence of a more smooth (as $p \in \mathbb{N})$ solution $q \in C^{p+2}([0, T], \mathcal{Y})$ of a regular problem.

Theorem 3. Let the pencil $\vec{B}$ be polynomially A-bounded and condition (A) be fulfilled, moreover, $C \in \mathcal{L}(\mathcal{X} ; \mathcal{Y}), \quad p \in \mathbb{N}_{0}, \Phi \in C^{p+2}([0, T] ; \mathcal{L}(\mathcal{Y} ; \mathcal{X})), h \in C^{p+2}([0, T] ; \mathcal{X})$, $\Psi \in C^{p+4}([0, T] ; \mathcal{Y})$, for any $t \in[0, T]$ operator $C \Phi(t)$ be invertible, with $(C \Phi)^{-1} \in$ $C^{p+2}([0, T] ; \mathcal{L}(\mathcal{Y}))$ and the compatibility condition $C u_{1}=\Psi^{\prime}(0)$ be satisfied for some $u_{1} \in \mathcal{U}$. Then there exists and a unique solution of (10)-(12), and $q \in C^{p+2}([0, T] ; \mathcal{Y})$.

Proof. Denote by $V_{11}=\frac{1}{2 \pi i} \int_{\gamma}\left(\mu^{2} A-\mu B_{1}-B_{0}\right)^{-1}\left(\mu A-B_{1}\right) e^{\mu t} d \mu$,

$$
\begin{aligned}
& V_{12}=\frac{1}{2 \pi i} \int_{\gamma}\left(\mu^{2} A-\mu B_{1}-B_{0}\right)^{-1} A e^{\mu t} d \mu, \\
& V_{21}=\frac{1}{2 \pi i} \int_{\gamma}\left(\mu^{2} A-\mu B_{1}-B_{0}\right)^{-1} B_{0} e^{\mu t} d \mu, \\
& V_{22}=\frac{1}{2 \pi i} \int_{\gamma}\left(\mu^{2} A-\mu B_{1}-B_{0}\right)^{-1} \mu A e^{\mu t} d \mu
\end{aligned}
$$

the propagators of the homogeneous equation (10). Earlier, in the proof of Theorem 2, it was established that the function $q(t)$ satisfies the integral equation (16). Take the natural number $n \leq p+2$. Assuming that $q \in C^{n}([0, T] ; \mathcal{Y})$ by Lemma 2 we obtain the equality

$$
\begin{aligned}
q^{(n)}(t) & =q_{0}^{(n)}(t)+\sum_{k=0}^{n-1} C_{n}^{k} R^{(k)}(t) C S_{0} \sum_{m=0}^{n-k-1} V_{12}^{(n-k-m-1)}(t)(\Phi q)^{(m)}(0)+ \\
+ & \sum_{k=0}^{n} \sum_{m=0}^{n-k} C_{n}^{k, m} R^{(k)}(t) C S_{0} \int_{0}^{t} V_{12}(t-s) \Phi^{(m)}(s) q^{(n-k-m)}(s) d s+ \\
& +\sum_{k=0}^{n-1} C_{n}^{k} R^{(k)}(t) C S_{1} \sum_{m=0}^{n-k-1} V_{22}^{(n-k-m-1)}(t)(\Phi q)^{(m)}(0)+ \\
+ & \sum_{k=0}^{n} \sum_{m=0}^{n-k} C_{n}^{k, m} R^{(k)}(t) C S_{1} \int_{0}^{t} V_{22}(t-s) \Phi^{(m)}(s) q^{(n-k-m)}(s) d s
\end{aligned}
$$

where $C_{n}^{k}=\frac{n !}{k !(n-k) !}, C_{n}^{k, m}=\frac{n !}{k ! m !(n-k-m) !}$ and

$$
\begin{array}{r}
q_{0}^{(n)}(t)=-\sum_{k=0}^{n} C_{n}^{k} R^{(k)}(t)\left(\Psi^{(n-k+2)}(t)-C S_{0} V_{11}^{(n-k)}(t) u_{0}-\right. \\
-C S_{1} V_{21}^{(n-k)}(t) u_{0}-C S_{0} V_{12}^{(n-k)}(t) u_{1}-C S_{1} V_{22}^{(n-k)}(t) u_{1}-
\end{array}
$$




$$
\begin{gathered}
-C S_{0} \int_{0}^{t} V_{12}(t-s) h^{(n-k)}(s) d s-C S_{1} \int_{0}^{t} V_{22}(t-s) h^{(n-k)}(s) d s- \\
\left.-C h^{(n-k)}(t)\right)+\sum_{k=0}^{n-1} C_{n}^{k} R^{(k)}(t) C S_{0} \sum_{m=0}^{n-k-1} V_{12}^{(n-k-m-1)}(t) h^{(m)}(0)+ \\
+\sum_{k=0}^{n-1} C_{n}^{k} R^{(k)}(t) C S_{1} \sum_{m=0}^{n-k-1} V_{22}^{(n-k-m-1)}(t) h^{(m)}(0)
\end{gathered}
$$

exists from the conditions of this theorem for $n=0,1, \ldots, p+2$.

Show that $q \in C^{p+2}([0, T], \mathcal{Y})$, for this purpose denote $r_{0}=q_{0}(0)$, and for $n=1,2, \ldots, p+2$ determine the following values

$$
\begin{gathered}
r_{n}=q_{0}^{(n)}(0)+\sum_{k=0}^{n-1} C_{n}^{k} R^{(k)}(0) C S_{0} \sum_{m=0}^{n-k-1} V_{12}^{(n-k-m-1)}(0) \sum_{l=0}^{m} C_{m}^{l} \Phi^{(l)}(0) r_{m-l}+ \\
+\sum_{k=0}^{n-1} C_{n}^{k} R^{(k)}(0) C S_{1} \sum_{m=0}^{n-k-1} V_{22}^{(n-k-m-1)}(0) \sum_{l=0}^{m} C_{m}^{l} \Phi^{(l)}(0) r_{m-l} .
\end{gathered}
$$

Consider the system of integral equations

$$
\begin{aligned}
\tilde{q}_{0}(t)=q_{0}(t) & +R(t)\left(C S_{0} \int_{0}^{t} V_{12}(t-s) \Phi(s) \tilde{q}_{0}(s) d s+C S_{1} \int_{0}^{t} V_{22}(t-s) \Phi(s) \tilde{q}_{0}(s) d s\right), \\
\tilde{q}_{n}(t)= & q_{0}^{(n)}(t)+\sum_{k=0}^{n-1} C_{n}^{k} R^{(k)}(t) C S_{0} \sum_{m=0}^{n-k-1} V_{12}^{(n-k-m-1)}(t) \sum_{l=0}^{m} C_{m}^{l} \Phi^{(l)}(0) r_{m-l}+ \\
& +\sum_{k=0}^{n-1} C_{n}^{k} R^{(k)}(t) C S_{1} \sum_{m=0}^{n-k-1} V_{22}^{(n-k-m-1)}(t) \sum_{l=0}^{m} C_{m}^{l} \Phi^{(l)}(0) r_{m-l}+ \\
& +\sum_{k=0}^{n} \sum_{m=0}^{n-k} C_{n}^{k, m} R^{(k)}(t) C S_{0} \int_{0}^{t} V_{12}(t-s) \Phi^{(m)}(s) \tilde{q}_{n-k-m}(s) d s+ \\
+ & \sum_{k=0}^{n} \sum_{m=0}^{n-k} C_{n}^{k, m} R^{(k)}(t) C S_{1} \int_{0}^{t} V_{22}(t-s) \Phi^{(m)}(s) \tilde{q}_{n-k-m}(s) d s, n=1, \ldots, p+2 .
\end{aligned}
$$

Reduce (19) to the Volterra equation of the second kind

$$
g(t)=g_{0}(t)+\int_{0}^{t} K(t, s) g(s) d s
$$

on the space $(C([0, T] ; \mathcal{Y}))^{p+3}$ with a matrix operator function $K(t, s)$ given on the triangle $\Delta=\left\{(t, s) \in \mathbb{R}^{2}: 0 \leq t \leq T, 0 \leq s \leq t\right\}$. By virtue of the continuity of all data of system (19), it has a unique solution

$$
\left(\tilde{q}_{0}, \tilde{q}_{1}, \ldots, \tilde{q}_{p+2}\right) \in(C([0, T] ; \mathcal{Y}))^{p+3} .
$$

This solution will be the limit of the sequence of approximations

$$
\tilde{q}_{0, i}(t)=q_{0}(t)+R(t)\left(C S_{0} \int_{0}^{t} V_{12}(t-s) \Phi(s) \tilde{q}_{0, i-1}(s) d s+C S_{1} \int_{0}^{t} V_{22}(t-s) \Phi(s) \tilde{q}_{0, i-1}(s) d s\right),
$$




$$
\begin{aligned}
\tilde{q}_{n, i}(t)= & q_{0}^{(n)}(t)+\sum_{k=0}^{n-1} C_{n}^{k} R^{(k)}(t) C S_{0} \sum_{m=0}^{n-k-1} V_{12}^{(n-k-m-1)}(t) \sum_{l=0}^{m} C_{m}^{l} \Phi^{(l)}(0) r_{m-l}+ \\
& +\sum_{k=0}^{n-1} C_{n}^{k} R^{(k)}(t) C S_{1} \sum_{m=0}^{n-k-1} V_{22}^{(n-k-m-1)}(t) \sum_{l=0}^{m} C_{m}^{l} \Phi^{(l)}(0) r_{m-l}+ \\
& +\sum_{k=0}^{n} \sum_{m=0}^{n-k} C_{n}^{k, m} R^{(k)}(t) C S_{0} \int_{0}^{t} V_{12}(t-s) \Phi^{(m)}(s) \tilde{q}_{n-k-m, i-1}(s) d s+ \\
+ & \sum_{k=0}^{n} \sum_{m=0}^{n-k} C_{n}^{k, m} R^{(k)}(t) C S_{1} \int_{0}^{t} V_{22}(t-s) \Phi^{(m)}(s) \tilde{q}_{n-k-m, i-1}(s) d s, n=1, \ldots, p+2, i \in \mathbb{N},
\end{aligned}
$$

which for $i \rightarrow \infty$ on the interval $[0, T]$ converge uniformly to the functions $\tilde{q}_{n}$, $n=0, \ldots, p+2$. Set the initial approximation $\tilde{q}_{n, 0} \equiv 0, n=0, \ldots, p+2$, then $\tilde{q}_{n+1,0}=\tilde{q}_{n, 0}^{\prime}$, $n=0, \ldots, p+1$. In addition, from (20) it follows that

$$
\tilde{q}_{n, i}(0)=r_{n}, \quad n=0, \ldots, p+2, \quad i \in \mathbb{N} .
$$

Assume that for all $j=1, \ldots, i$ the equalities $\tilde{q}_{n+1, j}(t)=\tilde{q}_{n, j}^{\prime}(t), n=0, \ldots, p+1$ are true. Then, using Lemma 2 and equalities (21), we obtain

$$
\begin{aligned}
& \frac{d}{d t}\left(\sum_{k=0}^{n} \sum_{m=0}^{n-k} C_{n}^{k, m} R^{(k)}(t) C S_{0} \int_{0}^{t} V_{12}(t-s) \Phi^{(m)}(s) \tilde{q}_{n-k-m, i}(s) d s\right)= \\
& =\sum_{k=1}^{n+1} \sum_{m=0}^{n-k+1} C_{n}^{k-1, m} R^{(k)}(t) C S_{0} \int_{0}^{t} V_{12}(t-s) \Phi^{(m)}(s) \tilde{q}_{n-k-m+1, i}(s) d s+ \\
& \quad+\sum_{k=0}^{n} C_{n}^{k} R^{(k)}(t) C S_{0} V_{12}(t) \sum_{m=0}^{n-k} C_{n-k}^{m} \Phi^{(m)}(0) r_{n-k-m}+ \\
& +\sum_{k=0}^{n} \sum_{m=1}^{n-k+1} C_{n}^{k, m-1} R^{(k)}(t) C S_{0} \int_{0}^{t} V_{12}(t-s) \Phi^{(m)}(s) \tilde{q}_{n-k-m+1, i}(s) d s+ \\
& \quad+\sum_{k=0}^{n} \sum_{m=0}^{n-k} C_{n}^{k, m} R^{(k)}(t) C S_{0} \int_{0}^{t} V_{12}(t-s) \Phi^{(m)}(s) \tilde{q}_{n-k-m+1, i}(s) d s .
\end{aligned}
$$

Denote by $a_{k, m}$ some values in (22). Taking into account the equalities

$$
C_{n}^{k}+C_{n}^{k-1}=C_{n+1}^{k}, \quad C_{n}^{k, m}+C_{n}^{k-1, m}+C_{n}^{k, m-1}=C_{n+1}^{k, m}
$$

we get

$$
\begin{gathered}
\sum_{k=0}^{n} \sum_{m=0}^{n-k} C_{n}^{k, m} a_{k, m}+\sum_{k=1}^{n+1} \sum_{m=0}^{n-k+1} C_{n}^{k-1, m} a_{k, m}+\sum_{k=0}^{n} \sum_{m=1}^{n-k+1} C_{n}^{k, m-1} a_{k, m}= \\
=\sum_{k=1}^{n} \sum_{m=1}^{n-k} C_{n+1}^{k, m} a_{k, m}+\sum_{k=1}^{n} C_{n+1}^{k, 0} a_{k, 0}+\sum_{m=1}^{n} C_{n+1}^{0, m} a_{0, m}+\sum_{k=1}^{n} C_{n+1}^{k, 0} a_{k, n-k+1}+ \\
+C_{n}^{0,0} a_{0,0}+C_{n}^{0, n} a_{0, n+1}+C_{n}^{n, 0} a_{n+1,0}=\sum_{k=0}^{n+1} \sum_{m=0}^{n-k+1} C_{n+1}^{k, m} a_{k, m} .
\end{gathered}
$$


From (22) and (23) it follows that

$$
\begin{gathered}
\frac{d}{d t}\left(\sum_{k=0}^{n} \sum_{m=0}^{n-k} C_{n}^{k, m} R^{(k)}(t) C S_{0} \int_{0}^{t} V_{12}(t-s) \Phi^{(m)}(s) \tilde{q}_{n-k-m, i}(s) d s\right)= \\
=\sum_{k=0}^{n+1} \sum_{m=0}^{n-k+1} C_{n+1}^{k, m} R^{(k)}(t) C S_{0} \int_{0}^{t} V_{12}(t-s) \Phi^{(m)}(s) \tilde{q}_{n-k-m+1, i}(s) d s+ \\
+\sum_{k=0}^{n} C_{n}^{k} R^{(k)}(t) C S_{0} V_{12}(t) \sum_{m=0}^{n-k} C_{n-k}^{m} \Phi^{(m)}(0) r_{n-k-m} .
\end{gathered}
$$

Similarly, we can get that

$$
\begin{gathered}
\frac{d}{d t}\left(\sum_{k=0}^{n} \sum_{m=0}^{n-k} C_{n}^{k, m} R^{(k)}(t) C S_{1} \int_{0}^{t} V_{22}(t-s) \Phi^{(m)}(s) \tilde{q}_{n-k-m, i}(s) d s\right)= \\
=\sum_{k=0}^{n+1} \sum_{m=0}^{n-k+1} C_{n+1}^{k, m} R^{(k)}(t) C S_{1} \int_{0}^{t} V_{22}(t-s) \Phi^{(m)}(s) \tilde{q}_{n-k-m+1, i}(s) d s+ \\
+\sum_{k=0}^{n} C_{n}^{k} R^{(k)}(t) C S_{1} V_{22}(t) \sum_{m=0}^{n-k} C_{n-k}^{m} \Phi^{(m)}(0) r_{n-k-m} .
\end{gathered}
$$

Changing the summation indices and re-grading the sums we get

$$
\begin{gathered}
\frac{d}{d t}\left(\sum_{k=0}^{n-1} C_{n}^{k} R^{(k)}(t) C S_{0} \sum_{m=0}^{n-k-1} V_{12}^{(n-k-m-1)}(t) \sum_{l=0}^{m} C_{m}^{l} \Phi^{(l)}(0) r_{m-l}\right)= \\
=\sum_{k=0}^{n} C_{n+1}^{k} R^{(k)}(t) C S_{0} \sum_{m=0}^{n-k} V_{12}^{(n-k-m)}(t) \sum_{l=0}^{m} C_{m}^{l} \Phi^{(l)}(0) r_{m-l}- \\
\quad-\sum_{k=0}^{n} C_{n}^{k} R^{(k)}(t) C S_{0} V_{12}(t) \sum_{m=0}^{n-k} C_{n-k}^{m} \Phi^{(m)}(0) r_{n-k-m} .
\end{gathered}
$$

Similarly, we get that

$$
\begin{gathered}
\frac{d}{d t}\left(\sum_{k=0}^{n-1} C_{n}^{k} R^{(k)}(t) C S_{1} \sum_{m=0}^{n-k-1} V_{22}^{(n-k-m-1)}(t) \sum_{l=0}^{m} C_{m}^{l} \Phi^{(l)}(0) r_{m-l}\right)= \\
=\sum_{k=0}^{n} C_{n+1}^{k} R^{(k)}(t) C S_{1} \sum_{m=0}^{n-k} V_{22}^{(n-k-m)}(t) \sum_{l=0}^{m} C_{m}^{l} \Phi^{(l)}(0) r_{m-l}- \\
-\sum_{k=0}^{n} C_{n}^{k} R^{(k)}(t) C S_{1} V_{22}(t) \sum_{m=0}^{n-k} C_{n-k}^{m} \Phi^{(m)}(0) r_{n-k-m} .
\end{gathered}
$$

Differentiating (20), and also using $(24)-(27)$, we obtain the equalities $\tilde{q}_{n, i+1}^{\prime}=$ $\tilde{q}_{n+1, i+1}, n=0, \ldots, p+1$. Thus, the sequence $\tilde{q}_{0, i}$ converges as $i \rightarrow \infty$ to the function $\tilde{q}_{0}$ uniformly on the interval $[0, T]$, and the sequence $\tilde{q}_{0, i}^{\prime}=\tilde{q}_{1, i}$ converges as $i \rightarrow \infty$ to the function $\tilde{q}_{1}$ uniformly on the segment $[0, T]$. Therefore, the function $\tilde{q}_{0}$ is continuously differentiable and $\tilde{q}_{0}^{\prime}=\tilde{q}_{1}$. The equalities of $\tilde{q}_{n}^{\prime}=\tilde{q}_{n+1}, n=1, \ldots, p+1$, are proved in the same way, which implies that $\tilde{q}_{0} \equiv q \in C^{p+2}([0, T] ; \mathcal{Y})$ and, therefore, $q^{(n)}=\tilde{q}_{n}$, $n=1, \ldots, p+2$. 


\section{Solvability of the Original Inverse Problem}

Now we can formulate the solvability conditions for the original problem (1) - (4).

Theorem 4. Let the pencil $\vec{B}$ be polynomially A-bounded and condition (A) be fulfilled, moreover, the $\infty$ be a pole of order $p \in \mathbb{N}_{0}$ of the A-resolvent of the pencil $\vec{B}$, operator $C \in \mathcal{L}(\mathcal{U} ; \mathcal{Y}), \mathcal{U}^{0} \subset$ ker $C, \chi \in C^{p+2}([0, T] ; \mathcal{L}(\mathcal{Y} ; \mathcal{F}))$, $f \in C^{p+2}([0, T] ; \mathcal{F}), \quad \Psi \in C^{p+4}([0, T] ; \mathcal{Y})$, for any $t \in[0, T]$ operator $C\left(A^{1}\right)^{-1} Q \chi$ be invertible, with $\left(C\left(A^{1}\right)^{-1} Q \chi\right)^{-1} \in C^{p+2}([0, T] ; \mathcal{L}(\mathcal{Y}))$, the condition $C u_{1}=\Psi^{\prime}(0)$ be satisfied at some initial value $u_{1}=v_{1} \in \mathcal{U}$, and the initial values $w_{k}=(I-P) v_{k} \in \mathcal{U}^{0}$ satisfy

$$
w_{k}=-\sum_{j=0}^{p} K_{j}^{2}\left(B_{0}^{0}\right)^{-1} \frac{d^{j+k}}{d t^{j+k}}[(I-Q)(\chi(0) q(0)+f(0))], \quad k=0,1
$$

Then there exists a unique solution $(v, q)$ of inverse problem (1) - (4), where $q \in C^{p+2}([0, T] ; \mathcal{Y}), \quad v=u+w$, whence $u \in C^{2}\left([0, T] ; \mathcal{U}^{1}\right)$ is the solution of (5) - (7) and the function $w \in C^{2}\left([0, T] ; \mathcal{U}^{0}\right)$ is a solution of (8), (9) given by

$$
w(t)=-\sum_{j=0}^{p} K_{j}^{2}\left(B_{0}^{0}\right)^{-1} \frac{d^{j}}{d t^{j}}[(I-Q)(\chi(t) q(t)+f(t))] .
$$

Proof. The conditions of Theorems 2 and 3 are satisfied, and therefore there exists a unique solution $(q, u)$ of problem $(5)-(7)$, where $q \in C^{p+2}([0, T] ; \mathcal{Y}), u \in C^{2}\left([0, T] ; \mathcal{U}^{1}\right)$.

Using the result of [17] and the required smoothness of the function $q$, we obtain that there exists a unique solution $w \in C^{2}\left([0, T] ; \mathcal{U}^{0}\right)$ to $(8)$, (9) given by $(28)$.

Acknowledgements. The work was supported by Act 211 Government of the Russian Federation, contract no. 02.A03.21.0011.

\section{References}

1. Wang S., Chen G. Small Amplitude Solutions of the Generalized IMBq Equation. Mathematical Analysis and Applications, 2002, vol. 274, pp. 846-866. DOI: 10.1016/S0022247X(02)00401-8

2. Uizem G. Linear and Nonlinear Waves. N.Y., Joyn Wiley and Sons, 1974.

3. Landau L.D., Lifshits E.M. Theoretical Phisics. Elasticity Theory. Vol. 7. London, Pergamon Press, 1970.

4. Favini A., Sviridyuk G.A., Manakova N.A. Linear Sobolev Type Equations with Relatively p-Sectorial Operators in Space of "Noises". Abstract and Applied Analysis, 2015, article ID: 697410, 8 p. DOI: $10.1155 / 2015 / 697410$

5. Fedorov V.E., Urazaeva A.V. Linear Inverse Evolution Problems for Sobolev Type. Non-Classical Equations of Mathematical Physics: Collection of Scientific Papers, 2010, pp. 293-310. 
6. Zagrebina S.A., Konkina A.S. The Multipoint Initial-Final Value Condition for the NavierStokes Linear Model. Bulletin of the South Ural State University. Series: Mathematical Modelling, Programming and Computer Software, 2015, vol. 8, no. 1, pp. 132-136. DOI: $10.14529 / \mathrm{mmp} 150111$

7. Manakova N.A., Sviridyuk G.A. An Optimal Control of the Solutions of the InitialFinal Problem for Linear Sobolev Type Equations with Strongly Relatively p-Radial Operator. Springer Proceedings in Mathematics and Statistics, 2015, vol. 113, pp. 213-224. DOI: $10.1007 / 978-3-319-12145-1 \_13$

8. Zamyshlyaeva A.A., Lut A.V. Numerical Investigation of the Boussinesq-Love Mathematical Models on Geometrical Graphs. Bulletin of the South Ural State University. Series: Mathematical Modelling, Programming and Computer Software, 2017, vol. 10, no. 2, pp. 137-143. DOI: $10.14529 / \mathrm{mmp} 170211$

9. Keller A.V., Sagadeeva M.A. The Optimal Measurement Problem for the Measurement Transducer Model with a Deterministic Multiplicative Effect and Inertia. Bulletin of the South Ural State University. Series: Mathematical Modelling, Programming and Computer Software, 2014, vol. 7, no. 1, pp. 134-138. DOI: 10.14529/mmp140111 (in Russian)

10. Bychkov E.V. On a Semilinear Sobolev-Type Mathematical Model. Bulletin of the South Ural State University, Series: Mathematical Modelling, Programming and Computer Software, 2014, vol. 7, no. 2, pp. 111-117. DOI: 10.14529/mmp140210 (in Russian)

11. Tsyplenkova O.N. Optimal Control in Higher-Order Sobolev-Type Mathematical Models with $(A, p)$-Bounded Operators. Bulletin of the South Ural State University. Series: Mathematical Modelling, Programming and Computer Software, 2014, vol. 7, no. 2, pp. 129-135. DOI: $10.14529 / \mathrm{mmp140213} \mathrm{(in} \mathrm{Russian)}$

12. Banasiak J., Lachowicz M., Moszynski M. Chaotic Behavior of Semigroups Related to the Process of Gene Amplification-Deamplification with Cell Proliferation. Mathematical Biosciences, 2007, vol. 206, no. 2, pp. 200-2015.

13. Zaynullov A.R. [An Inverse Problem for Two-Dimensional Equations of Finding the Thermal Conductivity of the Initial Distribution]. Bulletin of the Samara State Technical University. Series: Physics and Mathematics, 2015, vol. 19, no. 4, pp. 667-679. (in Russian)

14. Safiullova R.R. Inverse Problems for the Second Order Hyperbolic Equation with Unknown Time Depended Coefficient. Bulletin of the South Ural State University, Series: Mathematical Modelling, Programming and Computer Software, 2013, vol. 6, no. 4, pp. 73-86.

15. Megraliev Ya.T., Isgenderova Q.N. [Inverse Boundary Value Problem for a Second-Order Hyperbolic Equation with Integral Condition of the First Kind]. Problems of Physics, Mathematics and Technology, 2016, vol. 1, no. 26, pp. 42-47. (in Russian)

16. Pavlov S.S. Solvability of the Inverse Problem of Reconstruction of the External Action for a Multidimensional Wave Equation. Bulletin of the Chelyabinsk State University, 2011, vol. 26, pp. 27-37.

17. Zamyshlyaeva A.A, Sviridyuk G.A. Nonclassical Equations of Mathematical Physics. Linear Sobolev Type Equations of Higher Order. Bulletin of the South Ural State University. Series: Mathematics. Mechanics. Physics, 2016, vol. 8, no. 4, pp. 5-16. DOI: 10.14529/mmph160401

18. Prilepko A.I., Orlovsky D.G., Vasin I.A. Methods for Solving Inverse Problems in Mathematical Physics. N.Y., Marcel Dekker, 2000.

Received November 1, 2018 


\title{
ОБРАТНАЯ ЗАДАЧА ДЛЯ МАТЕМАТИЧЕСКИХ МОДЕЛЕЙ СОБОЛЕВСКОГО ТИПА
}

\author{
А.А. Замышляева ${ }^{1}$, А.В. Лут ${ }^{1}$ \\ ${ }^{1}$ Южно-Уральский государственный университет, г. Челябинск, \\ Российская Федерация
}

\begin{abstract}
Работа посвящена исследованию обратной задачи для линейного уравнения соболевского типа высокого порядка с неизвестным коэффициентом, зависящим от времени. Поскольку уравнение может быть вырожденным, используется метод фазового пространства. Он состоит в построении проекторов, расщепляющих исходные пространства в прямую сумму подпространств. Действия операторов также расщепляются. Таким образом, исходная модель сводится к двум задачам: регулярной и сингулярной. Регулярная редуцируется к невырожденной задаче первого порядка, которая решается с помощью аппроксимаций. Получена необходимая гладкость решения. Затем оно подставляется в сингулярную задачу, которая решается с использованием методов теории относительно полиномиально ограниченных пучков операторов. Основной результат работы содержит достаточные условия существования и единственности решения обратной задачи для математической модели соболевского типа второго порядка. Данная методика может быть использована при исследовании обратных задач рассматриваемого типа для математической модели Буссинеска - Лява.

Ключевые слова: уравнения соболевского типа; обратная задача; математические модели; уравнения второго порядка.
\end{abstract}

\section{Литература}

1. Wang, S. Small Amplitude Solutions of the Generalized IMBq Equation / S. Wang, G. Chen // Mathematical Analysis and Applications. - 2002. - V. 274. - P. 846-866.

2. Уизем, Дж. Линейные и нелинейные волны / Дж. Уизем. - М.: Мир, 1977.

3. Ландау, Л.Д. Теоретическая физика. Т. VII. Теория упругости / Л.Д. Ландау, Е.М. Лифшиц. - М.: Наука, 1987.

4. Favini, A. Linear Sobolev Type Equations with Relatively p-Sectorial Operators in Space of «Noises»/ A. Favini, G.A. Sviridyuk, N.A. Manakova // Abstract and Applied Analysis. 2015. - P. 1-8.

5. Федоров, В.Е. Линейная эволюционная обратная задача для уравнений соболевского типа / В.Е. Федоров, А.В. Уразаева // Неклассические уравнения математической физики. Новосибирск. - 2010. - С. 293-310.

6. Zagrebina, S.A. The Multipoint Initial-Final Value Condition for the Navier - Stokes Linear Model / S.A. Zagrebina, A.S. Konkina // Вестник ЮУрГУ. Серия: Математическое моделирование и программирование. - 2015. - Т. 8, № 1. - С. 132-136.

7. Manakova, N.A. An Optimal Control of the Solutions of the Initial-Final Problem for Linear Sobolev Type Equations with Strongly Relatively $p$-Radial Operator / N.A. Manakova, G.A. Sviridyuk // Semigroups of Operators - Theory and Applications. Springer Proceedings in Mathematics and Statistics. - 2015. - V. 113. - P. 213-224.

8. Zamyshlyaeva, A.A. Numerical Investigation of the Boussinesq-Love Mathematical Models on Geometrical Graphs / A.A. Zamyshlyaeva, A.V. Lut // Вестник ЮУрГУ. Серия: Математическое моделирование и программирование. - 2017. - Т. 10, № 2. - С. 137-143.

Вестник ЮУрГУ. Серия «Математическое моделирование

и программирование» (Вестник ЮУрГУ ММП). 2019. Т. 12, № 2. С. 25-36 
9. Келлер, А.В. Задача оптимального измерения для модели измерительного устройства с детерминированным мультипликативным воздействием и инерционностью / А.В. Келлер, М.А. Сагадеева // Вестник ЮУрГУ. Серия: Математическое моделирование и программирование. - 2014. - Т. 7, № 1. - С. 134-138.

10. Бычков, Е.В. Об одной полулинейной математической модели соболевского типа высокого порядка / Е.В. Бычков // Вестник ЮУрГУ. Серия: Математическое моделирование и программирование. - 2014. - Т. 7, № 2. - С. 111-117.

11. Цыпленкова, О.Н. Оптимальное управление в математических моделях соболевского типа высокого порядка с $(A, p)$-ограниченными операторами / О.Н. Цыпленкова // Вестник ЮУрГУ. Серия: Математическое моделирование и программирование. - 2014. T. 7, № 2. - C. 129-135.

12. Banasiak, J. Chaotic Behavior of Semigroups Related to the Process of Gene AmplificationDeamplification with Cell Proliferation / J. Banasiak, M. Lachowicz, M. Moszynski // Mathematical Biosciences. - 2007. - V. 206, № 2. - P. 200-2015.

13. Зайнуллов, А.Р. Обратная задача для двумерного уравнения теплопроводности по отысканию начального распределения / А.Р. Зайнуллов // Вестник Самарского государственного университета. Серия: Физико-математические науки. - 2015. - Т. 19, № 4. C. 667-679.

14. Сафиуллова, Р.Р. Обратная задача для гиперболического уравнения второго порядка с неизвестным коэффициентом, зависящим от времени / Р.Р. Сафиуллова // Вестник ЮУрГУ. Серия: Математическое моделирование и программирование. - 2013. - Т. 6, № 4. - C. 73-86.

15. Мегралиев, Я.Т. Обратная краевая задача для гиперболического уравнения второго порядка с интегральным условием первого рода / Я.Т. Мегралиев, Г.Н. Искендерова // Проблемы физики математики и технологий. - 2016. - Т. 1, № 26. - С. 42-47.

16. Павлов, С.С. Разрешимость обратной задачи восстановления внешнего воздействия в многомерном волновом уравнении / С.С. Павлов // Вестник ЧелГУ. - 2011. - Т. 26. C. $27-37$.

17. Замышляева, А.А. Неклассические уравнения математической физики. Линейные уравнения соболевского типа высокого порядка / А.А. Замышляева, Г.А. Свиридюк // Вестник ЮУрГУ. Серия: Математика. Механика. Физика. - 2016. - Т. 8, № 4. - С. 5-16.

18. Prilepko, A.I. Methods for Solving Inverse Problems in Mathematical Physics / A.I. Prilepko, D.G. Orlovsky, I.A. Vasin. - New York: Marcel Dekker, 2000.

Статья выполнена при поддержке Правительства РФ (Постановление № 211 om 16.03.2013 г.), соглашение № 02.A03.21.0011.

Алена Александровна Замышляева, доктор физико-математических наук, доцент, кафедра «Прикладная математика и программирование», ЮжноУральский государственный университет (г. Челябинск, Российская Федерация), zamyshliaevaaa@susu.ru.

Александр Валерьевич Лут, аспирант, кафедра «Прикладная математика и программирование», Южно-Уральский государственный университет (г. Челябинск, Российская Федерация), lutav@susu.ru.

Поступила в редакиию 1 ноября 2018 г. 